\title{
Сучасні підходи до фізичної реабілітації студенток з ожирінням та метаболічним Синдромом
}

\author{
УДК $613.25-055.2+577.12: 615.825-057.875$ \\ і. С. Миронюк, М. М. Дуб
}

Ужгородський національний університет, Ужгород, Україна

\begin{abstract}
Анотація. Мета. Вивчити підходи до побудови програм фізичної реабілітації студенток з ожирінням та метаболічним синдромом, визначити основні критерії для програмування і диференціації навантажень у процесі занять. Методи. Теоретичний аналіз фахової науково-методичної літератури та документальних матеріалів, антропометричні, фізіологічні, соціологічні, психодіагностичні методи дослідження, методи математичної статистики. Результати. Ефективність програмування реабілітаційних занять для осіб з ожирінням та ризиком розвитку метаболічного синдрому значною мірою залежить від якісного лікарсько-педагогічного контролю, коли спрямованість та інтенсивність занять підбираються індивідуально, залежно від показників фізичного та психоемоційного стану осіб. Критеріями індивідуалізації під час побудови програм для даного контингенту виступають показники фізичного та психоемоційного стану, якість життя. Нами було досліджено показники фізичного та психоемоційного стану, якість життя студенток з ожирінням. Встановлено, що абдомінальний тип ожиріння має негативний вплив на функціональний стан серцево-судинної системи. Виявлено, що ожиріння спричиняє зниження самооцінки, самоефективності, сприяє формуванню негативного ставлення до себе, що, в свою чергу, зумовлює зниження рівня комунікативних навичок i, насамкінець, знижує рівень упевненості їх у собі. Якість життя студенток з ожирінням можна охарактеризувати як нижчу за середню. Висновки. Ожиріння негативно впливає на якість життя і всі сфери діяльності людини, часто призводить до розвитку важких супутніх захворювань. Більшість досліджуваних осіб молодого віку з надмірною масою тіла та ожирінням відчувають об'єктивні труднощі внаслідок наявності серйозних відхилень у стані здоров'я, фізичних обмежень і психологічних проблем. Враховуючи негативний вплив ожиріння на здоров'я людей, високий ризик виникнення численних захворювань та ускладнень, необхідно виробити адекватний підхід до стійкого зниження маси тіла. Ключові слова: фізична реабілітація, ожиріння, метаболічний синдром, студентки, рухова активність, фізичний стан, психоемоційний стан, програма, якість життя.
\end{abstract}

\section{Modern approaches to physical rehabilitation of female students with obesity and metabolic syndrome}

\section{Myroniuk, M. Dub}

Uzhhorod National University, Uzhhorod, Ukraine

Abstract. Objective. To study the modern approaches to physical rehabilitation of female students with obesity and metabolic syndrome and to identify the main criteria for programming and differentiation of physical loads in the course of training. Methods. Theoretical analysis and generalization of special literature and documentary materials; anthropometric, physiological, sociological, and psychodiagnostic methods; methods of mathematical statistics. Results. The effectiveness of programming rehabilitation sessions for people with obesity and the risk of developing metabolic syndrome largely depends on the quality of medical and pedagogical monitoring, when the focus and intensity of the sessions are determined individually, depending on the characteristics of physical and psycho-emotional states of the people. The criteria of individualization of the program design for this group of 
people are the indices of physical and psycho-emotional states, and the quality of life. We examined the physical and psycho-emotional states and the quality of life of obese female students. It was found that the abdominal type of obesity has a negative impact on the functional state of the cardiovascular system. It is revealed that the presence of obesity in female students causes a decrease in their self-esteem and self-efficacy, contributes to the formation of a negative attitude to themselves, which in turn causes a decrease in the level of communication skills and, ultimately, reduces the level of self confidence. The quality of life of obese female students was below average. Conclusions. The obtained data indicate adverse effects of obesity on the quality of life and all areas of human activity, thus often leading to the development of serious comorbidities. Most of the involved young females with excess body weight and obesity experience objective difficulties due to severe health conditions, physical disabilities, and psychological problems. Given the negative impact of obesity on human health and the high risk of multiple diseases and complications, it is necessary to develop adequate approaches to sustained weight loss.

Keywords: physical rehabilitation, obesity, metabolic syndrome, female students, physical activity, physical state, psycho-emotional state.

Постановка проблеми. Надлишкова маса тіла та ожиріння, що призводять до значного погіршення рівня здоров'я населення та зростання ризику багатьох хронічних захворювань, $\epsilon$ однією з найгостріших проблем для більшості країн [1]. В усьому світі спостерігається тенденція до зростання поширеності даного захворювання. Згідно зі звітом Всесвітньої організації охорони здоров'я (ВООЗ) 39 \% світової популяції старше 18 років мають надлишкову масу тіла, а $13 \%$ - ожиріння; серед осіб 5-19 років 18,4 \% страждають від надмірної маси тіла та ожиріння. Значне занепокоєння викликає суттєве збільшення кількості осіб молодого віку з надмірною масою тіла та ожирінням. Як наголошується у сучасних дослідженнях, за останні роки поширеність ожиріння серед дітей віком від 6 до 11 років збільшилась 37 до $13 \%$, а серед підлітків 12-19 років майже в три рази - з 5 до $14 \%$ [11]. На сьогодні в економічно розвинутих країнах світу до $25 \%$ осіб молодого віку мають надмірну масу тіла, а 15 \% страждають від ожиріння.

Більшість авторів наголошують на тому, що ожиріння серед осіб молодого віку стане ключовою проблемою сучасного суспільства $[2,3,9$, 13], оскільки у молодому віці воно $є$ чинником, що обумовлює високу ймовірність розвитку серцево-судинних захворювань, цукрового діабету II типу, проблем опорно-рухового апарату, системи травлення, дихальної системи, психічних розладів, які суттєво впливають на якість життя.

На думку науковців, основною причиною виникнення надмірної маси тіла та ожиріння у студентської молоді $€$ порушення енергетичної рівноваги між спожитими та витраченими калоріями та низький рівень рухової активності, що пов'язаний з малорухливим способом життя сучасної молоді $[5,9]$. Ряд авторів підкреслюють важливість своєчасної корекції надмірної маси тіла у осіб молодого віку як головного фактора профрілактики розвитку ожиріння, метаболічного синдрому та ряду захворювань у більш зрілому віці $[1,3]$.

На даний час $є$ багато програм корекції надмірної маси тіла та ожиріння, які включають дієтотерапію, фрізичні навантаження та інше [3$5,7,9,14,15]$. Більшість 3 них орієнтовані на доросле населення та не мають клініко-функціонального обгрунтування стосовно інтенсивності, тривалості та кратності фрізичних навантажень. Корекція надмірної маси тіла серед осіб молодого віку має свої особливості та потребує більш поглибленої деталізації. Отже, пошук ефективних критеріїв для програмування і диференціації процесу реабілітаційних занять студенток 3 ожирінням та ризиком метаболічного синдрому $\epsilon$ актуальним. Результати таких досліджень дозволили б сформулювати підходи і практичні рекомендації для управління навантаженням в процесі занять фрізичною реабілітацією.

Дослідження виконано згідно з планом наукової роботи Ужгородського національного університету і $\epsilon$ фррагментом дослідження на теми: «Відновлення психофрізичного потенціалу організму осіб різного віку і статі, які мають відхилення у стані здоров'я, із застосуванням новітніх реабілітаційних технологій» (номер державної реєстрації 0116U003326) та «Підвищення психофрізичного потенціалу організму осіб різного віку і статі у процесі застосування новітніх моделей здоров'язбереження» (номер держреєстрації 0115U001748).

Мета дослідження - вивчити підходи до побудови програм фрізичної реабілітації студенток з ожирінням та метаболічним синдромом, визначити основні критерії для програмування і диференціації навантажень у процесі занять. 
Методи дослідження - теоретичний аналіз фахової науково-методичної літератури та документальних матеріалів, антропометричні, фрізіологічні, соціологічні, психодіагностичні методи дослідження, методи математичної статистики.

Результати дослідження. Ефеективність програмування реабілітаційних занять для осіб 3 ожирінням та ризиком розвитку метаболічного синдрому значною мірою залежить від якісного лікарсько-педагогічного контролю, коли спрямованість та інтенсивність занять підбираються індивідуально, залежно від показників фрізичного стану осіб. Дослідники наголошують, що критеріями індивідуалізації під час побудови програм для даного контингенту виступають показники фрізичного та психоемоційного стану, якість життя.

Вивчаючи специфрічні особливості фрізичного стану студенток 3 ожирінням, середньостатистичний вік яких становив $(18,53 ; 0,57)$ року, насамперед ми звернули увагу на їхній фрізичний розвиток та помітили, що стосовно маси тіла і обхвату грудної клітки середньостатистичні показники обстежених статично значуще $(p<0,05)$ відрізняються від даних, представлених у літературі, які відображають загальну картину фрізичного розвитку студентської молоді жіночої статі.

Індекс Кетле (IК) має важливе значення для скринінгових досліджень і виявлення осіб з ожирінням або схильних до нього з метою подальшої розробки програми зниження маси тіла. Середній рівень ІК становив $\left(30,55 ; 0,48 \mathrm{\kappa г} \cdot \mathrm{M}^{-2}\right)$. Його мінімальне значення відповідало $30,02 \mathrm{\kappa г} \cdot \mathrm{m}^{-2}$, а максимальне - 31,96 кг $\cdot \mathrm{m}^{-2}$. Таким чином, у всіх обстежуваних констатовано ожиріння першого ступеня. Розрахунок вмісту жиру засвідчив його значне перевищення від установлених норм, а також коливання показника від 37,6 до $39,3 \%$. Зазначимо, що середнє значення становило $(38,12 ; 0,42 \%)$.

Відомо, що для здоров'я найбільш несприятливим науковці вважають абдомінальний тип ожиріння, який часто супроводжується комплексом гормональних і метаболічних порушень, об'єднаних у «метаболічний синдром». Його визнано фрактором ризику розвитку серцево-судинних захворювань та цукрового діабету [12]. Таким чином, ураховуючи контингент обстежуваних, окрім загальноприйнятих показників, нами було виміряно показники фізичного розвитку, які в подальшому дали можливість розрахувати відношення обхвату талії до обхвату стегон учасниць дослідження і констатувати тип ожиріння. Розмах варіації обхвату талії у обстежуваних становив 18 см (від 82 до 100 см), а обхвату
ТАБЛИЦЯ 1 - Порівняльний аналіз показників фізичного розвитку студенток за типами ожирінням, $\bar{x} \pm \mathbf{S}$

\begin{tabular}{|l|c|c|}
\hline \multirow{2}{*}{\multicolumn{1}{|c|}{ Показники }} & \multicolumn{2}{|c|}{ Тип ожиріння } \\
\cline { 2 - 3 } & $\begin{array}{c}\text { абдомі- } \\
\text { нальний, } \mathbf{n}=12\end{array}$ & $\begin{array}{c}\text { глютеофе- } \\
\text { моральний, } \mathbf{n}=18\end{array}$ \\
\hline Довжина тіла, см & $\begin{array}{c}164,83 \pm \\
3,16\end{array}$ & $162,78 \pm 5,59$ \\
\hline Маса тіла, кг & $83,42 \pm 3,50$ & $80,78 \pm 5,46$ \\
\hline Індекс Кетле, кг· ${ }^{-2}$ & $30,69 \pm 0,55$ & $30,46 \pm 0,40$ \\
\hline Обхват грудної клітки, см & $104,67 \pm$ & $102,56 \pm 4,82$ \\
& 4,56 & \\
\hline Обхват талії, см & $93,00 * \pm 3,84$ & $86,61 \pm 4,34$ \\
\hline Обхват стегон, см & $104,08 \pm$ & $107,78 \pm 6,06$ \\
& 3,50 & \\
\hline Відношення обхвату талії & $0,89 \pm 0,03$ & $0,80 \pm 0,04$ \\
до обхвату стегон & & \\
\hline Вміст жирової маси, \% & $38,24 \pm 0,47$ & $38,04 \pm 0,38$ \\
\hline
\end{tabular}

* При р < 0,05 за критерієм Стьюдента для нормально розподілених вибірок.

** При р <0,05 за критерієм Манна-Уітні для інших.

стегон - 20 см (від 98 до 118 см). Виявлено, що середнє значення обхвату становило $(89,17$; 5,17 см). При цьому обхват стегон знаходився на рівні $(106,30 ; 5,41$ см). Аналіз індивідуальних значень відношення обхвату талії до обхвату стегон у студенток з ожирінням дає уявлення про значні коливання показника, який варіює від 0,712 до 0,941, що вказує на значні відмінності концентрації жиру в обстежуваних. Виявлено, що $60 \%$ студенток характеризувалися абдомінальним типом ожиріння. Оскільки реабілітація осіб з ожирінням безпосередньо залежить від його типу, для подальших досліджень студенток було розподілено на дві групи: з абдомінальним та глютеофеморальним типами ожиріння (табл. 1).

Подальше дослідження ми спрямували на встановлення показників фрункціонального стану ССС студенток й на розрахунок на їхній основі спеціальних індексів, оскільки за оцінками науковців ожиріння, особливо абдомінального типу, збільшує ризик захворювань ССС. Виявлено, що показники та індекси фрізичного розвитку студенток, окрім обхвату талії, статистично значуще $(p<0,05)$ не відрізняються залежно від типу ожиріння. Вивчення показників функціонального стану ССС досліджуваних залежно від типу ожиріння показало, що у студенток з абдомінальним типом ожиріння ЧСС на 13,9 \% перевищувало ЧСС студенток 3 глютеофеморальним типом ожиріння (табл. 2).

Стосовно АТ у студенток з абдомінальним типом ожиріння виявилась таке перевищення показників: $\mathrm{AT}_{\text {сист }}-$ на 8,2 \%, $\mathrm{AT}_{\text {діаст }}-$ на 9,8\%. Водночас доведено, що зареєстровані відмінності $\epsilon$ статистично значущими $(p<0,05)$. Аналіз 
ТАБЛИЦЯ 2 - Порівняльний аналіз показників та індексів функціонального стану серцево-судинної системи студенток за типами ожирінням

\begin{tabular}{|c|c|c|c|c|c|c|c|c|c|c|}
\hline \multirow{3}{*}{ Показники } & \multicolumn{10}{|c|}{ Тип ожиріння } \\
\hline & \multicolumn{5}{|c|}{ абдомінальний, $\mathrm{n}=12$} & \multicolumn{5}{|c|}{ глютеофеморальний, n = 18} \\
\hline & $\overline{\mathrm{x}}$ & Me & $25 \%$ & $75 \%$ & s & $\overline{\mathbf{x}}$ & Me & $25 \%$ & $75 \%$ & $\mathbf{s}$ \\
\hline \multicolumn{11}{|c|}{ Показники } \\
\hline ЧСС, уд $\cdot \mathrm{xB}^{-1}$ & $100,8^{*}$ & 101,0 & 95,0 & 107,5 & 9,6 & 88,4 & 88,0 & 85,0 & 94,0 & 6,6 \\
\hline $\mathrm{AT}_{\text {сист, }}, \mathrm{MM} \mathrm{рт.} \mathrm{ст.}$ & $128,3^{* *}$ & 130,0 & 120,0 & 135,0 & 9,4 & 118,6 & 120,0 & 110,0 & 120,0 & 6,1 \\
\hline $\mathrm{AT}_{\text {діact }}$, мM рт. ст. & $84,6^{\star *}$ & 85,0 & 80,0 & 90,0 & 7,2 & 77,1 & 80,0 & 70,0 & 80,0 & 6,1 \\
\hline \multicolumn{11}{|c|}{ Індекси } \\
\hline Робінсона (IP), ум. од. & $129,9^{*}$ & 133,8 & 116,3 & 145,6 & 20,7 & 105,0 & 103,9 & 96,0 & 112,5 & 11,5 \\
\hline Квааса, ум. од. & $23,1^{*}$ & 22,8 & 21,3 & 24,7 & 1,9 & 21,4 & 21,9 & 20,5 & 22,5 & 2,5 \\
\hline Кердо, ум. од. & 15,6 & 15,6 & 10,9 & 21,5 & 6,7 & 12,6 & 13,0 & 9,1 & 16,7 & 6,3 \\
\hline
\end{tabular}

* При р < 0,05 за критерієм Стьюдента для нормально розподілених вибірок

** При $\mathrm{p}<0,05$ за критерієм Манна-Уітні для інших.

індексів, отриманих на основі показників учасниць дослідження, дозволив відтворити загальну картину фрункціонального стану ССС. Значення індексу Робінсона у студенток з абдомінальним типом ожиріння на 23,7 \% більше, тобто функціональний резерв їх ССС статистично значуще (p < 0,05) менший, ніж у студенток із глютеофеморальним типом ожиріння. 3'ясувалося, що порівняно зі студентками із глютеофеморальним типом ожиріння, індекс витривалості Квааса у обстежуваних із абдомінальним типом ожиріння на 7,8\% більший, що свідчить про статистично значущий (р < 0,05) нижчий ступінь тренованості їх ССС до виконання фрізичного навантаження. Незважаючи на відсутність статистично значущих ( $p>0,05)$ відмінностей, дослідження показало, що вегетативний індекс Кердо у студенток з глютеофеморальним типом ожиріння на 19,2\% менший, ніж у студенток із абдомінальним типом ожиріння. При цьому функціональна рівновага в діяльності вегетативної нервової системи спостерігалась у 27,7 \% (n= 5) студенток із глютеофеморальним типом ожиріння та в 25,0\% ( $n=3$ ) учасниць 3 абдомінальним типом ожиріння. Відтак підтвердилося, що абдомінальний тип ожиріння у жінок більш небезпечний, оскільки має негативний вплив на функціональний стан ССС.

Подальше дослідження показало збільшення показника адаптаційного потенціалу у студенток даної категорії незалежно від типу ожиріння, що вказує на напруження в них процесів адаптації. Однак у студенток із абдомінальним типом ожиріння середнє значення цього показника становило (2,82; 0,28 ум. од.), що статистично значуще $(p<0,05)$ більше порівняно зі студентками 3 глютеофеморальним типом, у яких цей показник становив (2,48; 0,18 ум. од.).

Загалом обстежувані із глютеофеморальним типом ожиріння характеризувалися середнім рівнем фрізичного стану, на що вказує індекс фрізичного стану (ІФС), який становив $(0,54$; 0,09 ум. од.). Натомість у студенток із абдомінальним типом значення ІФС становив $(0,37 ; 0,13$ ум. од.), що свідчить про низький рівень їхнього фрізичного стану. Крім того, доведено, що ІФС студенток має статистично значущі $(p<0,05)$ відмінності залежно від типу ожиріння. Водночас зафріксовано зростання середнього значення індексу Руф'є у студенток із глютеофеморальним типом ожиріння (11,59; 2,31 ум. од.) та у студенток із абдомінальним типом (13,75; 1,98 ум. од.). Зареєстровано статистично значуще ( $<<0,05)$ зростання індексу Руф'є у студенток із абдомінальним типом ожиріння порівняно зі студентками з глютеофеморальним типом, що вказує на істотне зниження їхньої фрізичної працездатності.

Розподіл студенток за рівнями фрізичної працездатності дозволив встановити, що серед студенток із глютеофеморальним типом ожиріння на $36,1 \%$ менше характеризуються низьким рівнем та на 13,9 \% більше 3 нижчим за середній рівнем фрізичної працездатності порівняно зі студентками з абдомінальним типом. Якщо в студенток із глютеофеморальним типом ожиріння 22,2 \% характеризувалося середнім рівнем фрізичної працездатності, то в студенток із абдомінальним типом таких не виявлено взагалі. Таким чином, ожиріння має негативний вплив на адаптаційний потенціал, рівень фрізичного стану і фрізичну працездатність студенток, проте 
абдомінальний тип ожиріння призводить до ще більш тяжких наслідків.

У ході дослідження 3 метою встановлення впливу ожиріння на психоемоційні показники студенток було оцінено рівень їх самооцінки, рівень комунікабельності та вольової саморегуляції. За методикою С. Будассі, інтегрованою Ю. Я. Кисельовим [6], виявлено, що у студенток, які характеризуються ожирінням, уявлення про себе не співпадає з ідеальним уявленням про особистісні якості, які їм імпонують та якими б вони хотіли би володіти (рис. 1).

Коефіцієнти самооцінки у обстежуваних варіюються від -0,31 до 0,62. Підрахунки коефріцієнтів засвідчили, що лише $16,7 \%(n=5)$ студенток мають адекватну оцінку. При цьому $3,3 \%(n=1)$ з них характеризується завищеною самооцінкою, натомість у $20,0 \%(n=6)$ спостерігається різке несприйняття себе як особистості, на що вказує від'ємне значення коефріцієнта самооцінки. Таким чином, можна стверджувати, що ожиріння має негативний вплив на самооцінку студенток.

Як одну із важливих якостей для успішного навчання та подальшої професійної самореалізації, за допомогою діагностики рівня комунікативних умінь нами було визначено рівень комунікабельності студенток з ожирінням. Розподіл студенток з ожирінням за рівнями комунікабельності показав, що середнє значення по групі становило $(24,9 ; 4,9$ бала), що за класифрікатором становить 25 балів і вказує на граничну межу між певною комунікабельністю та замкненістю опитуваних. Дійсно, розподіл студенток з ожирінням за рівнями комунікабельності підтвердив, що серед студенток $з$ ожирінням превалює частка замкнених і мовчазних, які віддають перевагу самотності. Таких виявилося 53,3 \%. Інтерпретація результатів діагностики рівня комунікативних умінь студенток $з$ ожирінням показала таке:

- 13,3\% респонденток мали критичний рівень комунікабельності, що зумовлює серйозні проблеми в комунікативній сорері: на таких осіб не можна покластися у справі, що потребує колективних зусиль i яким рекомендовано бути більш комунікабельними та контролювати себе;

- 53,3 \% характеризувалися пасивним рівнем комунікабельності, що свідчить про їх замкненість, схильність до самотності;

- 20 \% характеризувалися базовим рівнем, тобто володіють певною комунікабельністю й в незнайомій обстановці почувають себе цілком упевнено;

- у $10 \%$ зареєстровано оптимальний рівень комунікабельності, тобто студентки характеризувалися нормальною комунікабельністю.

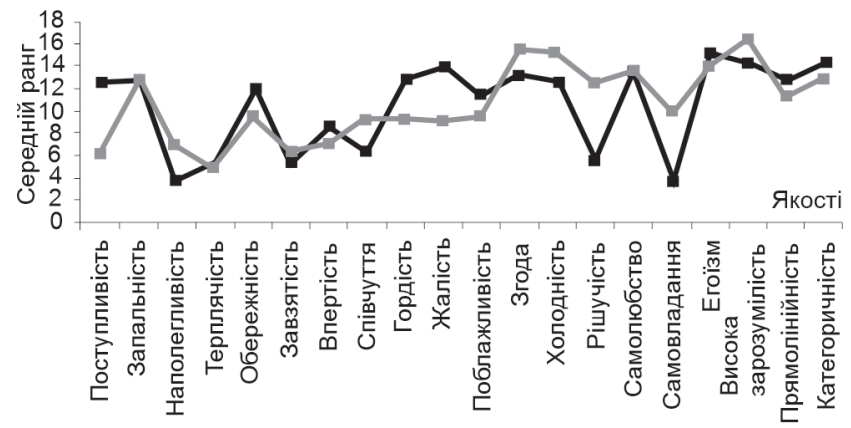

Рисунок 1 - Порівняння ідеальних та наявних особистісних якостей студенток з ожирінням $(n=30)$ :

$\_-$ідеал; $=--$самооцінка

Як бачимо, ожиріння негативно впливає на рівень комунікативних умінь студенток, не сприяє бажанню колективно працювати, висловлювати власну точку зору й відстоювати ії, відвідувати нові місця й розширювати коло однодумців і колег. На нашу думку, вирішення проблеми ожиріння сприятиме підвищенню рівня комунікабельності студенток.

3 метою виявлення рівня самоефективності особистості студенток з ожирінням було використано методику вивчення загальної самоефективності особистості Р. Шварцера, М. Ерусалема в адаптації В. Ромека [6]. Показники коливалися в межах від 16 до 35 балів і в середньому знаходилися на рівні $(21,3 ; 4,6$ бала), що вказує на низьку самоефективність учасниць дослідження.

Кореляційний аналіз результатів психодіагностики студенток 3 ожирінням показав, що існує:

- прямий статистично значущий $(p<0,05)$ взаємозв'язок $(r=0,43)$ між рівнем самооцінки та самоефективності обстежуваних, що показує на зростання оцінки самоефективності разом зі збільшенням самооцінки студенток;

- обернений статистично значущий $(p<0,05)$ взаємозв'язок $(r=-0,53)$ між рівнем самооцінки та комунікабельності обстежуваних, що свідчить про зниження оцінки комунікабельності, а відтак - про збільшення рівня комунікативних здібностей та підвищення самооцінки;

- тісний обернений статистично значущий $(p<0,05)$ взаємозв'язок $(r=-0,79)$ між рівнем самоефективності та комунікабельності обстежуваних, що свідчить про зростання результатів тестування та зумовлює підвищення їх самоефективності.

Таким чином, ожиріння у студенток спричиняє зниження їх самооцінки, самоефективності, сприяє фоормуванню негативного ставлення до себе, що, в свою чергу, зумовлює зниження рівня комунікативних навичок i, насамкінець, знижує 
рівень впевненості у собі. Відтак, зниження рівня впевненості у собі слід розглядати як один із найбільш мотивуючих фракторів для залучення студенток з ожирінням до занять.

Загальне уявлення про особливості якості життя студенток 3 ожирінням було ссрормовано на основі комплексної характеристики, отриманої шляхом обчислення загальних параметрів рухової активності, ролі фрізичних проблем в обмеженні життєдіяльності, рівня болю, загального стану здоров'я, соціальної активності та ролі емоційних проблем в обмеженні життєдіяльності.

Оцінювання якості життя здійснювалося за методикою SF-36. Значення за шкалою «Фізична активність», яке становило (52,0; 18,83 бала), свідчить про суттєві обмеження щоденної діяльності респондента у зв'язку зі станом здоров'я. Показник зв'язку між фрізичним станом та виконанням повсякденних завдань у $(70,0 ; 34,37$ бала) знаходиться на такому рівні, який характерний в інших країнах світу для осіб з гострими чи хронічними захворюваннями і ще більш низький, ніж у дівчат старшого шкільного віку. Максимально низьким виявився показник загального стану здоров'я. Показники життєздатності значно нижчі, ніж представлені в літературі, що свідчить про відчуття безсилля, виснаження, характерне для студенток даної категорії. Це вказує на тенденцію до інертності студентської молоді, низький життєвий тонус, нездатність до будь-якої активності і неспроможність знайти вектор докладання своїх сил. А надзвичайно низькі показники соціальної активності лише підтверджують виявлену тенденцію до помітного зниження їхньої життєвої активності. У студенток з ожирінням переважає схильність до депресій, тривожності, апатії, що негативним чином впливає на їхню щоденну активність.

Слід зазначити, що у студенток з ожирінням показники ролі фрізичних та емоційних проблем в обмеженні життєдіяльності можуть бути співвіднесеними з показниками студенток з нормальним співвідношенням довжини й маси тіла, проте всі інші показники якості життя значно нижчі, ніж незадовільні показники генеральної сукупності студенток (за даними інших досліджень) (рис. 2).

Дослідження показало, що значення загального фрізичного компонента якості життя студенток $з$ ожирінням становило (48,06; 5,26 бала), а загального психічного компонента - $(42,16 ; 7,62$ бала), тобто якість їхнього життя можна охарактеризувати як нижчу за середню. Ми переконані, що в низьких показниках благополуччя студенток вирішальну роль відіграють надлишкова

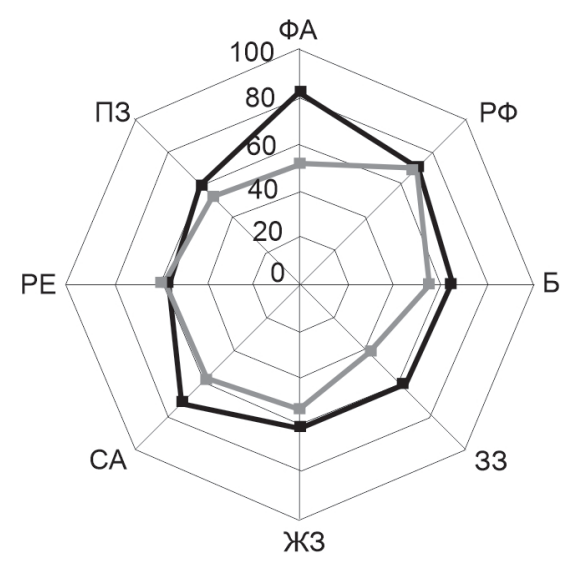

Рисунок 2 - Якість життя студенток з ожирінням (дослідження проведено за методикою SF-36; значення показників якості життя представлено в балах):

$\because-$ - студентки з ожирінням ( $=30) ;--$ студентки $(n=420)$

маса тіла та ожиріння. Отже, на нашу думку, за рахунок заходів, спрямованих на підвищення рухової активності студенток, можна вирішити не лише завдання оптимізації їхньої маси тіла, а й підвищення якості життя.

Висновки та перспективи подальших досліджень. Системний аналіз наукової літератури з проблеми дослідження дозволив визначити, що ефективність програмування реабілітаційних занять для осіб з ожирінням та ризиком розвитку метаболічного синдрому значною мірою залежить від якісного лікарсько-педагогічного контролю, коли спрямованість та інтенсивність занять підбираються індивідуально, залежно від показників фрізичного та психоемоційного станів осіб. 3 огляду на це, розробка наукових засад індивідуалізації тренувального процесу жінок із ожирінням $€$ актуальним, сучасним напрямом досліджень, що дозволяє створити найоптимальніші програми, спрямовані на максимальну результативність занять та сприятиме запобіганню розвитку патологій, що супроводжують ожиріння.

Створення системи первинного контролю та наукові розробки програм фрізичної реабілітації з урахуванням особливостей осіб із ожирінням дасть змогу швидше досягти бажаного ефекту під час зниження маси тіла. Дослідники наголошують, що критеріями індивідуалізації під час побудови програм для даного контингенту виступають показники фрізичного та психоемоційного стану, якість життя. Нами було досліджено показники фрізичного та психоемоційного стану, якість життя студенток з ожирінням. На основі отриманих результатів підтверджено дані фрахової літератури, які свідчать про те, що ожиріння негативно впливає на якість життя і всі сфрери діяльності людини, часто приводячи до розвитку 
важких супутніх захворювань. Більшість досліджуваних осіб молодого віку з надмірною масою тіла та ожирінням відчувають об'єктивні труднощі внаслідок наявності серйозних відхилень у стані здоров'я, фрізичних обмежень і психологічних проблем. Враховуючи негативний вплив ожиріння на здоров'я людей, високий ризик виникнення численних захворювань та ускладнень необхідно виробити адекватний підхід до стійкого зниження

\section{Література}

1. Андрєєва О, Нагорна А. Оцінка інформативності окремих антропометричних показників для проектування самостійних занять оздоровчим фрітнесом жінок зрілого віку з надлишковою масою тіла [Evaluation of the informativeness of individual anthropometric indices for planning of independent fitness trainings of mature women with overweight]. Молодіжний науковий вісник Східноєвропейського національного університету імені Лесі Українки. Фізичне виховання і спорт. 2018;30:54-8.

2. Єрмоленко НО, Зарудна ОІ, Голик IB. Ожиріння - проблема сучасності [Obesity - the problem of modernity]. Medceстринство. 2016;1:23-6.

3. Жарова І. Сучасний погляд на проблему застосування засобів фрізичної реабілітації в осіб з первинною конституціонально-екзогенною формою ожиріння [Contemporary view on the problem of the use of physical rehabilitation in persons with primary constitutionally-exogenous form of obesity]. Теорія і методика фрізичного виховання і спорту. 2014;1:28-31.

4. Колядич ОІ. Особливості комплексної фрізичної реабілітації при ожирінні । ступеня осіб працездатного віку. \{Peculiarities of complex physical rehabilitation during I degree obesity of working age persons\} Актуальні проблеми навчання та виховання людей з особливими потребами. 2010;7(9):501-8.

5. Копочинська ЮВ. Фізична реабілітація студенток з ожирінням та низьким рівнем фрізичної підготовленості [Physical rehabilitation of female students with obesity and low physical fitness] [автореферат]. Львів; 2012. 21 c.

6. Краснорядцева ОМ, Кабрин ВИ, Муравьева ОИ, Подойницина МА, Чучалова ОН. Психологические практики диагностики и развития самоэффективности студенческой молодежи [Psychological practices of diagnosis and development of self-efficacy in student youth]: учеб. пособие. Томск: Издательский Дом ТГУ; 2014. 274 с.

7. Марченко О, Івановська О. Ожиріння жінок другого зрілого віку - багатофакторне захворювання: версії, теорії, дискусії [Obesity in women of the second mature age - multifactor disease: versions, theories, discussions]. Теорія і методика фрізичного виховання і спорту. 2017;3:25-9. маси тіла. Особливо це стосується молодих людей, у яких неправильно сорормовані моделі поведінки, що в майбутньому може стати основою виникнення та прогресування різноманітних патологічних станів.

Подальші дослідження будуть спрямовані на розробку програми фрізичної реабілітації студенток з ожирінням та метаболічним синдромом та оцінювання іï̈ ефрективності.

8. Нагорна Н, Андрєєва О. Використання інформаційних технологій у процесі проектування профілактичнооздоровчих занять жінок зрілого віку [Usage of information technologies in the process of projecting preventive and healthrelated sessions for mature age females]. Теорія і методика фрізичного виховання і спорту. 2018;2:78-82.

9. Овдій МО. Застосування програми дозованої ходьби та дихальних вправ для корекції надмірної ваги у осіб молодого віку [The application of the program of walking and breathing exercises for the correction of overweight in young people] [дисертація]. Київ; 2015. 139 с.

10. Ожиріння та його наслідки [Obesity and its effects]: метод. вказівки для студ. мед. фрак. Харків; 2016. Доступно на: http://vnmed3.kharkiv.ua/wp-content/uploads/2013/12/23- \%D0 \%9E \%D0 \%B6 \%D0 \%B8 \%D1 \%80.pdf

11. Потеркова ВА, Ремизов ОВ. Ожирение в детском возрасте [Obesity in childhood]. Дедова ИИ, Мельниченко ГА, редакторы. Москва: МИА; 2006. 329с.

12. Ткаченко ВІ, Багро ТО, Видиборець НВ, Бондар ОК. Метаболічний синдром: діагностика та профрілактика в практиці сімейного лікаря [Metabolic syndrome: diagnostics and prevention in family doctor practice]. Ліки України. 2016;12(197-198):43-6.

13. Козак XI, Марущак MI. Поширеність аліментарного ожиріння і фактори, що сприяють його розвитку [Prevalence of alimentary obesity and factors that contribute to its development]. [Інтернет]. 2015 Груд 16 [цитовано 2017 Серп 07];0(3). Доступно на: https://ojs.tdmu.edu.ua/index.php/nursing/article/ view $/ 5375$

14. Wadden TA, Webb VL, Moran CH, Bailer BA. Lifestyle modification for obesity: new developments in diet, physical activity, and behavior therapy. Circulation. 2012;125:1157-70.

15. Lazareva O, Aravitska M, Andrieieva O, Galan Y \& Dotsyuk L. Dynamics of physical activity status in patients with grade i-iii obesity in response to a physical rehabilitation program. Journal of Physical Education and Sport. 2017;17(3):1960-5. DOI: 10.7752/jpes.2017.03193 